\title{
MINERALOGY AND GEOCHEMISTRY OF THE TRIADES- GALANA PB-ZN-AG-AU INTERMEDIATE-HIGH SULFIDATION EPITHERMAL MINERALIZATION, MILOS ISLAND, GREECE
}

\author{
Papavasiliou K. ${ }^{1}$, Voudouris P. ${ }^{2}$, Kanellopoulos C. ${ }^{3}$, Alfieris D. ${ }^{4}$ and Xydous S. ${ }^{2}$ \\ ${ }^{1}$ Faculty of Geology and Geoenvironment, University of Athens, Department of Economic Geology \\ and Geochemistry, Panepistimiopolis A. Ilisia 15784 Athens/Greece, papavas@geol.uoa.gr \\ ${ }^{2}$ Faculty of Geology and Geoenvironment, University of Athens, Department of Petrology, \\ Panepistimiopolis A. Ilisia15784 Athens/Greece,voudouris@geol.uoa.gr,stxydous@geol.uoa.gr \\ ${ }^{3}$ Institute of Geology and Mineral Exploration, $1^{\text {st }}$ Spirou Louis St., Olympic Village, 13677, \\ Acharnae, Greece, ckanellopoulos@gmail.com \\ ${ }^{4}$ Imerys Filtration, 15A Metaxa Street, Kifisia 14564, Greece, Dimitris.Alfieris@imerys.com
}

\begin{abstract}
The Triades-Galana Pb-Zn-Ag-Au mineralization is a shallow-submarine epithermal mineralization located along NE-trending faults, NW Milos Island, Greece. It is hosted in 2.5-1.4 Ma pyroclastic rocks and is genetically related to andesitic/dacitic lava domes. Mineralization occurs as breccias, quartz-barite-galena veins and stockworks within sericite-adularia or kaolinitic altered rocks. The mineralization is enriched in Mo, W and base- and precious metals (e.g. Pb, Zn, Ag) similarly to the neighbouring mineralization at Kondaros-Katsimouti and Vani, indicating common source of metals from a deep buried granitoid feeding western Milos with metals and volatiles. Paragenetic relations suggest early deposition of pyrite, followed by famatinite, polybasite and Ag-rich tetrahedrite, and then by enargite, suggesting fluctuating sulfidation states during ore formation. The evolution from Sb-towards As-rich enrichment indicate a renewed magmatic pulse (probably in the form of magmatic gases) in the hydrothermal system. Silver is present in the structure of sulfosalts (up to $66.2 \mathrm{wt}$.\% in polybasite-pearceite, $15.1 \mathrm{wt}$ \% in tetrahedrite and 60 $w t . \%$ in pyrargyrite). Boiling processes (as evidenced by the presence of adularia accompanying intermediate-sulfidation ore) and mixing with seawater (presence of hypogene lead chlorides) and contemporaneous uplift, contributed to ore formation. Keywords: Silver mineralogy, epithermal, Triades-Galana, Milos Island
\end{abstract}

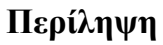

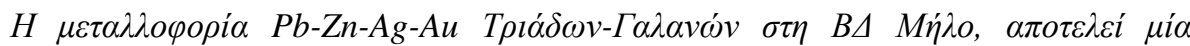

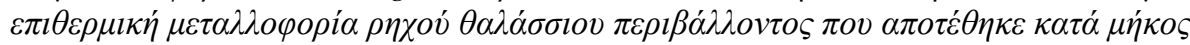

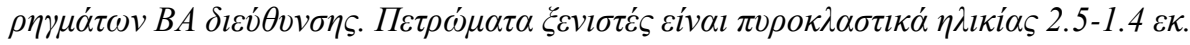

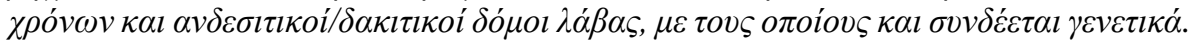

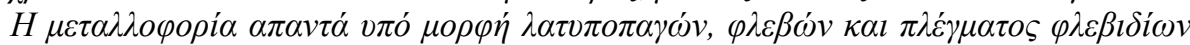

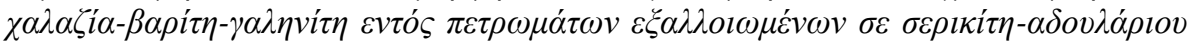

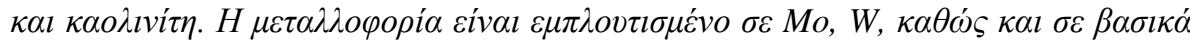




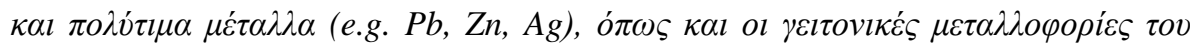

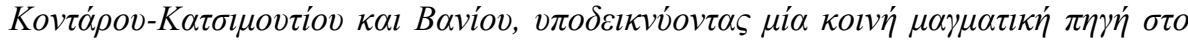

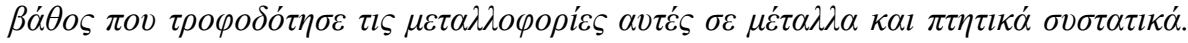

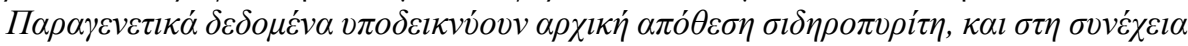

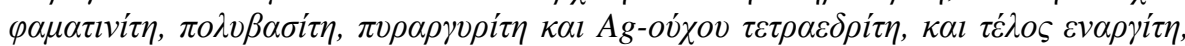

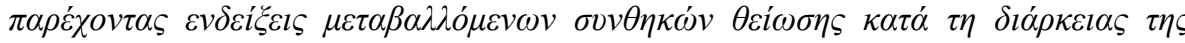

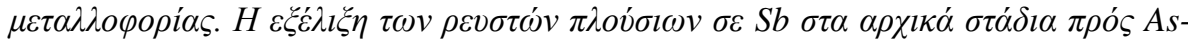

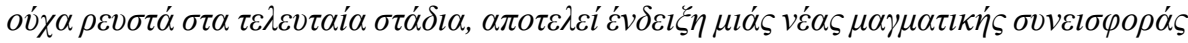

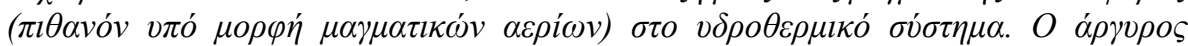

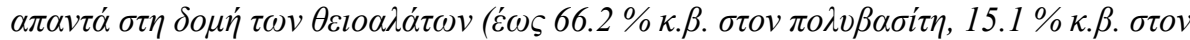

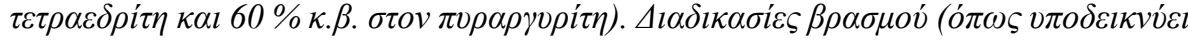

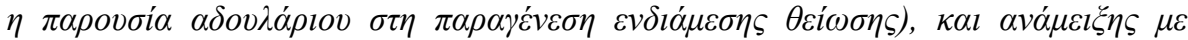

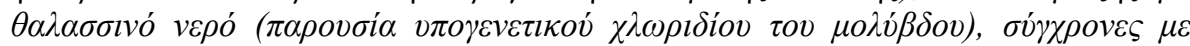
$\alpha v \alpha ́ \delta v \sigma \eta \tau \eta \varsigma \pi \varepsilon \rho l o \chi \eta ́ \varsigma, ~ \varepsilon ́ \chi o v v ~ \sigma v v \varepsilon l \sigma \varphi \varepsilon ́ \rho \varepsilon l ~ \sigma \tau \eta v ~ \alpha \pi o ́ \theta \varepsilon \sigma \eta ~ \tau o v ~ \mu \varepsilon \tau \alpha \lambda \lambda \varepsilon \dot{\mu} \mu \alpha \tau o \varsigma$.

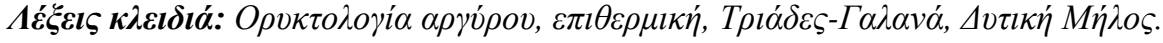

\section{Introduction}

Milos Island is one of the most densely mineralized areas in Greece, characterized by epithermal $\mathrm{Au}-\mathrm{Ag}$ and base metal deposition within a Plio-Pleistocene volcanic edifice. Metallic mineralization on Milos was the subject of several mineralogical and geochemical studies, with base- and precious metal mineralization in western Milos Island having been classified as either Kuroko- (Hauck, 1988; Vavelidis and Melfos, 1998), seawater-dominated epithermal (Kilias et al., 2001; Liakopoulos et al., 2001; Marchik et al., 2010), shallow submarine epithermal- (Alfieris, 2006; Stewart and McPhie, 2006; Alfieris et al., 2013), or hybrid volcanogenic massive sulfide (VMS)-epithermal types (Naden et al., 2005). A modern analogue for the setting of epithermal - style mineralization in western Milos is the shallow submarine Kolumbo hydrothermal vent field located $7 \mathrm{~km} \mathrm{NE}$ of Santorini Island in the Hellenic arc (Kilias et al., 2013). As suggested by Plimer (2000) and Stewar $\mathrm{t}$ and McPhie (2006), the Triades-Galana mineralization represents sub-seafloor/seafloor stockwor $\mathrm{k}$ zones, which formed in a shallow submarine setting. The Triades-Galana system is classified as $\mathrm{i}$ ntermediate- to high-sulfidation epithermal type (Alfieris and Voudouris, 2005; Marschik et al., 20 10). Probable resources of the Galana mine, according to Liakopoulos et al. (2001), were estimated to be 10 million tones with a mean concentration of $\mathrm{Ag}$ of $500 \mathrm{mg} / \mathrm{kg}$. Reported indicative resource $\mathrm{s}$ at Triades-Galana are 1.2 Mt at $1 \mathrm{~g} / \mathrm{t} \mathrm{Au}$ and $124 \mathrm{~g} / \mathrm{t} \mathrm{Ag} \mathrm{(Stewart} \mathrm{and} \mathrm{McPhie,} \mathrm{2003).} \mathrm{Since} \mathrm{there}$ is no detail exploration in this area until now, all the above estimations are very approximate.

The aim of the current study is to present new data on the metallic mineralization at Triades-Galana area, to describe its mineralogical and geochemical characteristics and discuss the role of various physico-chemical processes (e.g. boiling, mixing, etc.) in its formation by comparing it with other mineralized areas in western Milos and elsewhere.

\section{Geology and mineralization}

Milos Island forms part of the Cycladic Blueschist in the Attico-Cycladic massif, a polymetamorphic terrane within the Alpine orogen of the Hellenides (Jolivet and Brun, 2010). Miocene extension in the Aegean Sea was accompanied by the intrusion and extrusion of magmatic rocks at upper crustal levels (Altherr and Siebel, 2002). Milos is located in the central part of the Lower Pliocene to Recent South Aegean Active Volcanic Arc, which includes a belt of calc-alkaline volcanic centers consisting mainly of basalts, andesites, dacites, and rhyolites (Fig. 1, Fytikas et al., 1986). It comprises mainly Neogene sediments and volcanic rocks overlying a metamorphic basement that consists of eclogites, glaucophane schists and mica schists (Alfieris et al. 2013; Fytikas et al., 1986; Stewart and McPhie, 2006). The earliest volcanic episode (Middle to Upper Pliocene, 3.5-3.0 Ma) produced a succession of felsic submarine units including pumice flows, tuffs and pumice rich 
pyroclastic flows, with locally intrusive subvolcanic bodies, lavas and/or hyaloclastites. Some volcanosedimentary products have been deposited in E-W directed grabens from 3.0 to 2.7 Ma. The subsequent phase of submarine volcanism (Upper Pliocene-Lower Pleistocene, 2.7-1.4 Ma) is characterized by the emplacement of dacitic/andesitic domes, plugs and lava flows along a system of mainly NE-trending faults, and subordinately along NW-SE to E-W directions. These domes intruded and disrupted the still fluid and unconsolidated volcanosedimentary unit, suggesting contemporaneous emplacement in a shallow seawater environment. Based on SHRIMP U-Pb in zircon, Stewart and McPhie (2006) dated submarine dacite lavas at 2.18 \pm 0.09 Ma and submarine to subaerial daciticrhyodacitic flow banded domes and their autobreccias at $1.44 \pm 0.08 \mathrm{Ma}$ (both at Triades). The effusive activity was accompanied locally by explosive episodes, which locally produced bedded pumiceous tuff cones and/or pyroclastic flows and breccias in submarine and partially subaerial environments. The dominant structural features on western Milos Island are a series of steep, NE trending structures, which are characterized by left lateral strike-slip and dip-slip motion, and from the other side, a series of dilational NW trending lineament zones, into which composite volcanic centers, domes, and collapsed calderas developed. These zones limited the magmatic-hydrothermal fluid flow, producing zones of intense silicification, brecciation, and veining.

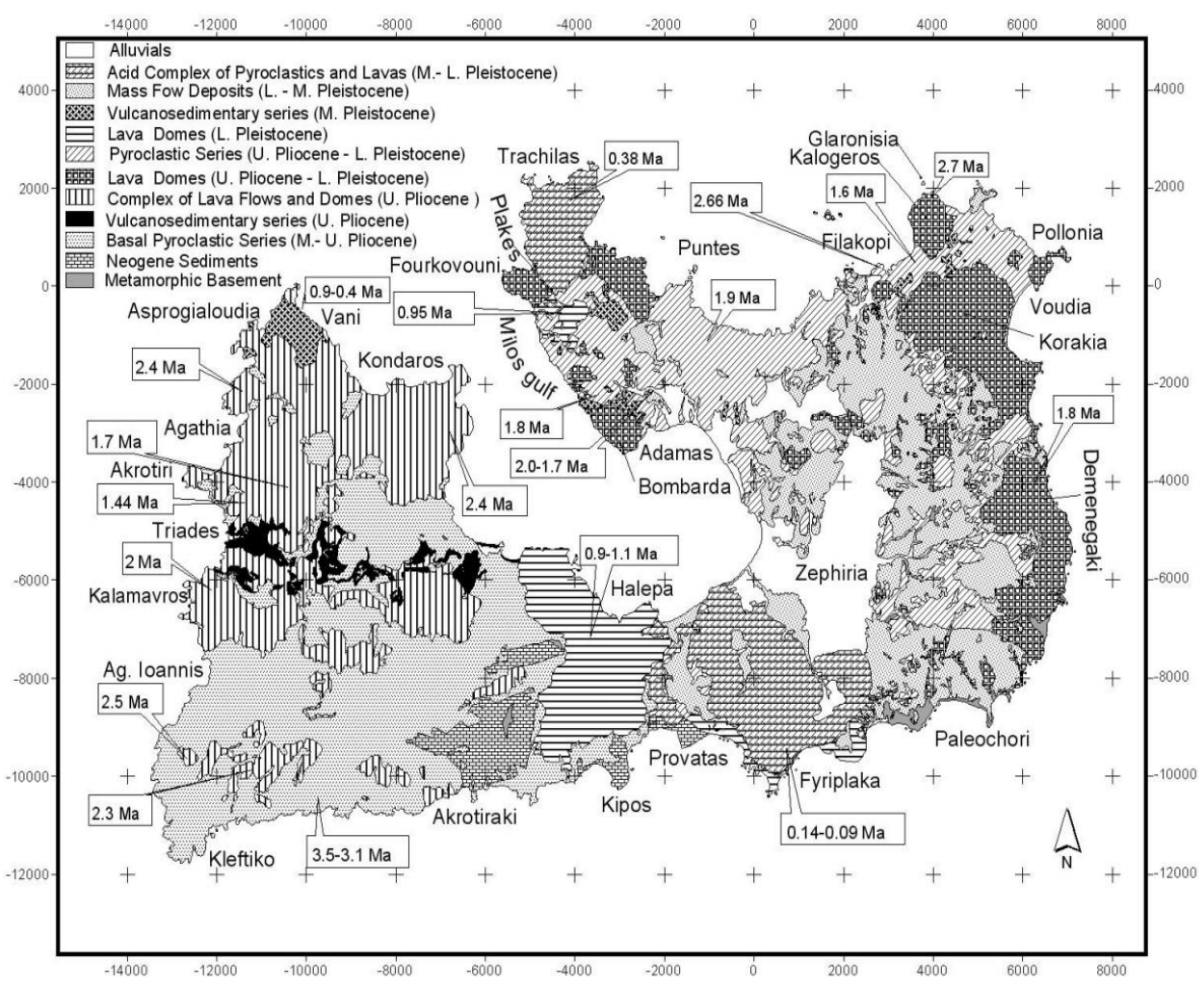

Figure 1 - Geological map of Milos Island showing the distribution of the main volcanic phases, metamorphic and sedimentary units, as well as geochronological data (after Fytikas et al., 1986; Alfieris, 2006).

The Triades-Galana area is located along the NE-trending Triades-Katsimoutis lineament. The host rocks to the mineralization are submarine ash flow tuffs, fossil-bearing tuffs, tuffaceous and epiclastic marine sediments, as well as andesitic or dacitic flow domes. The flow domes are genetically related to the mineralization, and were subject to kaolinite-sericite and alunitic alteration. In the Galana area, the dominant alteration is quartz-sericite-pyrite. The mineralization and associated hydrothermal alteration are spatially related to NE-trending faults and occurs as breccia 
zones and quartz-barite-galena veins or stockworks, crosscutting quartz-sericite-kaolinite and quartz-kaolinite/alunite altered breccia fragments (Alfieris et al., 2013). Barite, kaolinite, sericite, adularia and quartz are the gangue minerals. The textural features of the Triades-Galana ore indicate early deposition of pyrite with inclusions of bornite+digenite and Fe-poor sphalerite. This was succeeded by a metallic mineral assemblage composed of galena, tetrahedrite-tennantite, chalcopyrite, enargite, famatinite, pyrargyrite, polybasite, and covellite (Alfieris et al., 2013).

\section{Materials and methods}

The mineralogical composition of nineteen samples was investigated by reflected light microscopy (Leica DM 2500P), powder X-ray diffraction (XRD) and scanning electron microscopy-equipped with energy dispersive spectroscopy (SEM-EDS). The Triades samples included TR-1 (silicified and pyritized breccia, containing barite); TR-2 (argillized, silicified and sulfur impregnated dacite); TR-3 (quartz-barite \pm sphalerite vein cutting through a dacite; malachite staining is present); TR-4 (quartzbarite vein with sphalerite); TR-5 (galena-sphalerite mineralized, silicified dacite with veinlets of barite); TR-6 (quartz-barite veinlets and crustiform/colloform chalcedony veinlets cutting through a silicified dacite); TR-7 (quartz-sphalerite \pm barite vein cutting through a chalcedony/silicified volcaniclastic sandstone); TR-8 (silicified hyaloclastite containing fine-grained pyrite, marcasite and barite); TR-9 (hyaloclastite fragments impregnated with barite, silica and sphalerite, galena); TR-10 (hyaloclastite fragments impregnated with barite, silica and sphalerite, galena); TR-11 (fragments of silicified hyaloclastite containing pyrite-marcasite and barite); TR-12 and TR-13 (hyaloclastite fragments impregnated with galena, barite and sphalerite within a silicified matrix); The Galana samples included GA-1 (silicified, brecciated contact between a dacite intruded through mudstones); GA-2 (brecciated and silicified dacite-hyaloclastite); GA-3 (silicified dacitie with some oxidation most probably of pyrite. Barite is present); GA-4 and GA-5 (silicified dacite with sphalerite and barite); GA6 (argillized and partially silicified dacite with disseminated spalerite, barite).

The XRD study was carried out using a Siemens Model 5005 X-ray diffractometer in combination with the DIFFRAC plus software package. The diffractometer was operated using $\mathrm{Cu} \mathrm{K} \alpha$ radiation at $40 \mathrm{kV}$ and $40 \mathrm{~mA}$ and employing the following scanning parameters: step size $0.020^{\circ}$ and step time from 1.0 to $20.0 \mathrm{sec}$. The raw files (XRD diagrams) were evaluated for mineralogical identifications using the EVA 10.0 software. For microprobe analyses and SEM imaging we used a JEOL JSM 5600 scanning electron microscope, equipped with an automated energy dispersive analyses system ISIS 300 OXFORD, with the following operating conditions: accelerating voltage $20 \mathrm{kV}$, beam current $0.5 \mathrm{nA}$, time of measurement $50 \mathrm{~s}$ and beam diameter 1-2 mm. The spectra were processed using the ZAF software.

Samples were also digested with a mixture of $\mathrm{HClO} 4-\mathrm{HNO} 3-\mathrm{HF}$ acids and were analysed for a series of trace elements using Inductively Coupled Plasma-Atomic Emission Spectrometry (ICP-AES) and Inductively Coupled Plasma-Atomic Emission Spectroscopy (ICP-MS) and for a series of major elements by Inductively Coupled Plasma-Optical Emission Spectrometry (ICP-OES) at the Department of Chemistry, University of Gottingen, Germany.

\section{Analytical results}

\subsection{Mineralogy and mineral chemistry}

The main mineralogical composition of the studied samples (XRD analysis) are presented in Table 1. Representative microanalyses of metallic mineral phases are presented in Table 2 and all data of Agbearing sulfosalts are plotted in figure 3 . Table 1 demonstrates abundance of galena, sphalerite and pyrite accompanying quartz, adularia and sericite in all samples. In sample TR-3 the rare sulfosalt watanabeite (e.g. Shimizu et al., 1993) was detected, however, this could not be verified by the microprobe analyses. It follows a description of the metallic mineral phases in Triades-Galana area: 
Galena is a major constituent of the metallic mineralization assemblage at the Triades-Galana. Galena is the main host of Ag-sulfosalts, which usually, appear as inclusions (Fig. 2). It contains up to 0.09 wt. \% $\mathrm{Sb}$ and no $\mathrm{Ag}$ and $\mathrm{Bi}$ (Table 2).

Sphalerite replaces galena, is Fe-poor $(<0.71$ wt. \%) and contains $\mathrm{Cd}$ and $\mathrm{Mn}$ (up to 0.2 wt. \%; Table 2).

Pyrite is associated with polybasite, pyrargyrite and Ag-rich tetrahedrite, included in galena (Fig. $2 b$ to $d)$.

Enargite is a common mineral in the metallic paragenesis of Triades; it postdates galena and Agtetrahedrite (Fig. 2e). The analysed grains contain up to 2.57 wt. \% Ag (Table 2). Alfieris et al. (2013) reported enargite with up to $7.1 \mathrm{wt}$. \% Ag.

Famatinite, the Sb-analogue to enargite, is a common mineral at Triades. It appears either as isolated crystals or in association with polybasite and tetrahedrite, both included in galena (Fig. 2f, g). The analyzed famatinites contain up to: 3.3 wt. \% Ag, 0.39 wt. \% Zn, 1 wt. \% As, 0.18 wt. \% Cd and 0.71 wt. $\% \mathrm{Fe}$ (Table 2).

Tetrahedrite accompanies Sb-bearing sulfosalts (e.g. polybasite, pyrargyrite and famatinite) in the mineralization (Fig. 2). Already Vavelidis and Melfos (1997) presented Ag-rich and Pb-rich tetrahedrite in the area, and Alfieris et al. (2013) reported both tennantite and tetrahedrite coexisting in the same sample, with a dominance of tennantite over tetrahedrite, especially during late-stage ore deposition. Although previously only zincian tetrahedrite varieties have been reported (Alfieris et al., 2013), this study also demonstrates $\mathrm{Cd}$ - and $\mathrm{Hg}$ - tetrahedrite varieties with up to $7.37 \mathrm{wt} \%$ $\mathrm{Cd}$ and up to 7.42 wt \% $\mathrm{Hg}$ respectively (Table 2). Ag content up to 15.07 wt. \% and $\mathrm{Pb}$ up to 9.34 wt. \% were also detected (Table 2). $\mathrm{Cd}, \mathrm{Hg}$ and $\mathrm{Pb}$ substitute for $\mathrm{Zn}$ in the fahlore structure.

Pyrargyrite-proustite solid solution has reported by many researchers in Triades-Galana (Vavelidis and Melfos, 1997, 1998; Liakopoulos et al., 2001; Alfieris et al., 2013). Based on the microanalyses conducted during the present study, only pyrargyrite was found (Table 2, Fig. 3). It occurs in association with tetrahedrite as inclusion in galena (Fig. 2b, c, g, h).

Polybasite-pearceite solid solution occurs either as monomineralic rounded and/or lath-shaped grains included in galena, or in assemblages with Ag-tetrahedrite and pyrite or famatinite (Fig. 2a, b, d). Polybasite-pearceite solid solution contains up to 4.76 wt. \% As (Table 1, Fig. 3).

Lead chloride with a structural formula $\mathrm{PbCl}_{2}$ was found at Triades in the form of subrounded inclusions in galena (Fig. 2i).

\subsection{Bulk ore geochemistry}

Selected bulk geochemical analyses from epithermal veins and silicified and/or adularia-sericitic altered samples, rich in metallic mineral phases i.e. galena, sphalerite are presented in Table 3 . The Triades samples are enriched in molybdenum (up to $265 \mathrm{mg} / \mathrm{kg}$ ), above the molybdenum geochemical anomaly (up to $176 \mathrm{mg} / \mathrm{kg}$ ) identified by Alfieris et al. (2013) along two NE-trending Triades-Katsimouti lineament, which controls the surface distribution of silicic- and advanced argillic alteration in northwestern Milos Island. The studied samples from both areas are enriched in tungsten (e.g. Triades up to $848 \mathrm{mg} / \mathrm{kg}$ and Galana up to $440 \mathrm{mg} / \mathrm{kg}$ ). 
Table 1 - Semi-quantitative (XRD) mineralogical estimation of the samples from Triades (TR) and Galana (GA) area.

\begin{tabular}{|c|c|c|c|c|c|c|c|c|c|c|c|}
\hline & Bar & San & Cris & $\mathbf{Q z}$ & Sph & Gal & Pyr & Wat & Ill & Alu & Tetr \\
\hline $\begin{array}{c}\text { TR- } \\
1\end{array}$ & $* *$ & $* * * *$ & & $* * * * *$ & & & & & & & \\
\hline $\begin{array}{c}\text { TR- } \\
2\end{array}$ & & & $* *$ & $* * * * *$ & & & & & & $* * *$ & \\
\hline $\begin{array}{c}\text { TR- } \\
\mathbf{3} \\
\end{array}$ & $* * * * *$ & & & $* * * * *$ & $*$ & $*$ & & $* * *$ & & & $* *$ \\
\hline $\begin{array}{c}\text { TR- } \\
4\end{array}$ & $*$ & & & $* * * * *$ & $* *$ & $*$ & $*$ & & & & \\
\hline $\begin{array}{c}\text { TR- } \\
5\end{array}$ & $* *$ & $*$ & & $* * * *$ & $* * * *$ & $* *$ & & & & & \\
\hline $\begin{array}{c}\text { TR- } \\
6\end{array}$ & $* * * *$ & & & $* * *$ & $* *$ & $*$ & & & & & \\
\hline $\begin{array}{c}\text { TR- } \\
7 \\
\end{array}$ & $* *$ & $*$ & & $* * * * *$ & $* * *$ & $* *$ & & & & & \\
\hline $\begin{array}{c}\text { TR- } \\
8\end{array}$ & $* * *$ & & & $* * * * *$ & & & & & & & \\
\hline $\begin{array}{c}\text { TR- } \\
9\end{array}$ & $* * * * *$ & & & $* * * *$ & $* * * *$ & $* *$ & $*$ & & & & \\
\hline $\begin{array}{c}\text { TR- } \\
10\end{array}$ & $* * * *$ & & & $* * * * *$ & $* * *$ & $* *$ & $*$ & & & & \\
\hline $\begin{array}{c}\text { TR- } \\
11\end{array}$ & $* * *$ & & & $* * * * *$ & $*$ & & $* *$ & & & & \\
\hline $\begin{array}{c}\text { TR- } \\
12\end{array}$ & $* * * * *$ & & & $* * * *$ & $* * *$ & $* *$ & $*$ & & & & \\
\hline $\begin{array}{c}\text { TR- } \\
13\end{array}$ & $* * *$ & $*$ & & $* * * *$ & $* * *$ & $* *$ & $*$ & & & & \\
\hline $\begin{array}{c}\text { GA- } \\
1 \\
\end{array}$ & & $* *$ & & $* * * * *$ & & & & & $*$ & & \\
\hline $\begin{array}{c}\text { GA- } \\
2\end{array}$ & & $* * * * *$ & & $* *$ & & & & & $* * *$ & & \\
\hline $\begin{array}{c}\text { GA- } \\
\mathbf{3}\end{array}$ & $* * *$ & $* * *$ & $* * *$ & $* * * * *$ & & & & & $* * *$ & & \\
\hline $\begin{array}{c}\text { GA- } \\
4 \\
\end{array}$ & tr. & $* *$ & & $* * * * *$ & $* * *$ & $*$ & $*$ & & $*$ & & \\
\hline $\begin{array}{c}\text { GA- } \\
5\end{array}$ & & $* *$ & & $* * * * *$ & $* * *$ & $*$ & & & $* *$ & & \\
\hline $\begin{array}{c}\text { GA- } \\
6\end{array}$ & $*$ & $* *$ & & $* * * * *$ & $* * * *$ & & & & tr. & & \\
\hline
\end{tabular}




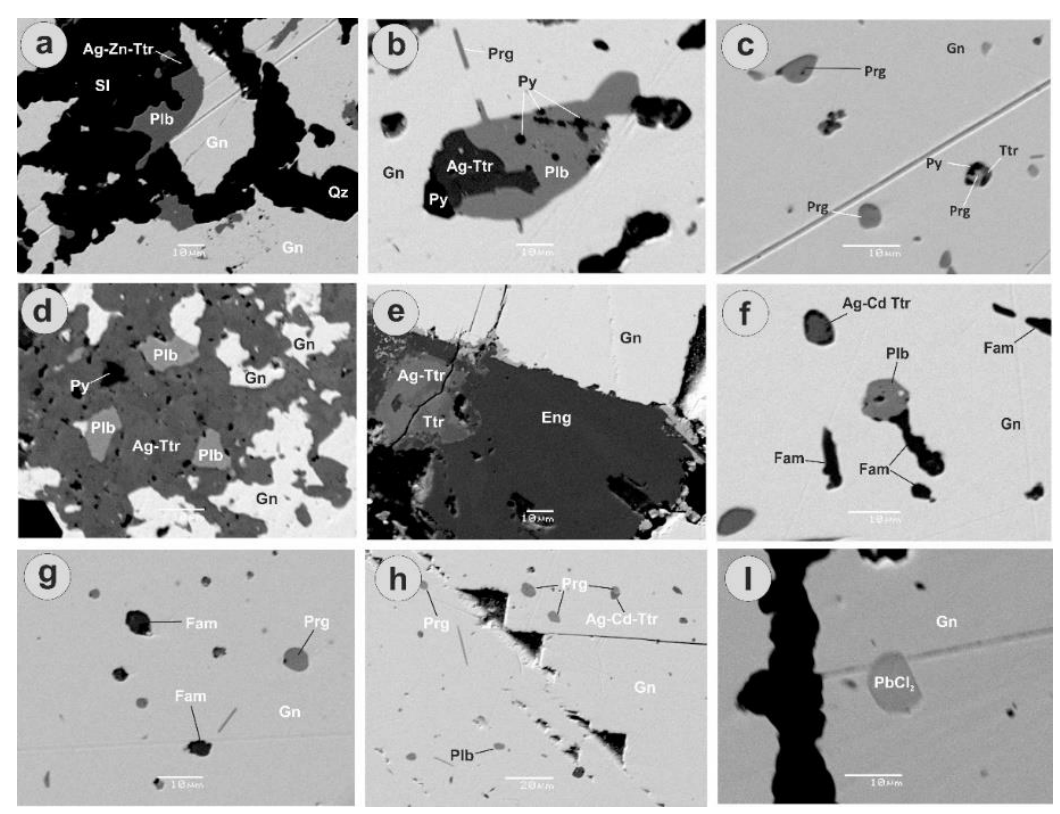

Figure 2 - Photomicrographs (SEM-BSE images) demonstrating ore assemblages at Triades-Galana mineralization: (a) Galena (Gn), polybasite (Plb) and Ag-Zn-rich tetrahedrite (Ag-Zn-Ttr) are replaced by sphalerite (SI). Quartz (Qz) is also present, (b) Pyrite (Py) associated with polybasite and Ag-rich tetrahedrite, and pyrargyrite (Prg) are included in galena, (c) Pyrite associated with pyrargyrite and

tetrahedrite are included in galena, (d) Polybasite-galena intergrowths are replaced by Ag-rich tetrahedrite. Pyrite is also present, (e) Galena is surrounded by Ag-rich tetrahedrite and enargite (Eng), (f) Famatinite (Fam) intergrown with polybasite and Ag-Cd-rich tetrahedrite (Ag-Cd-Ttr) are included in galena, (g) Famatinite and pyrargyrite are included in galena, (h) Pyrargyrite, polybasite and Ag-Cdrich tetrahedrite are included in galena, (i) Lead chloride is included in galena.

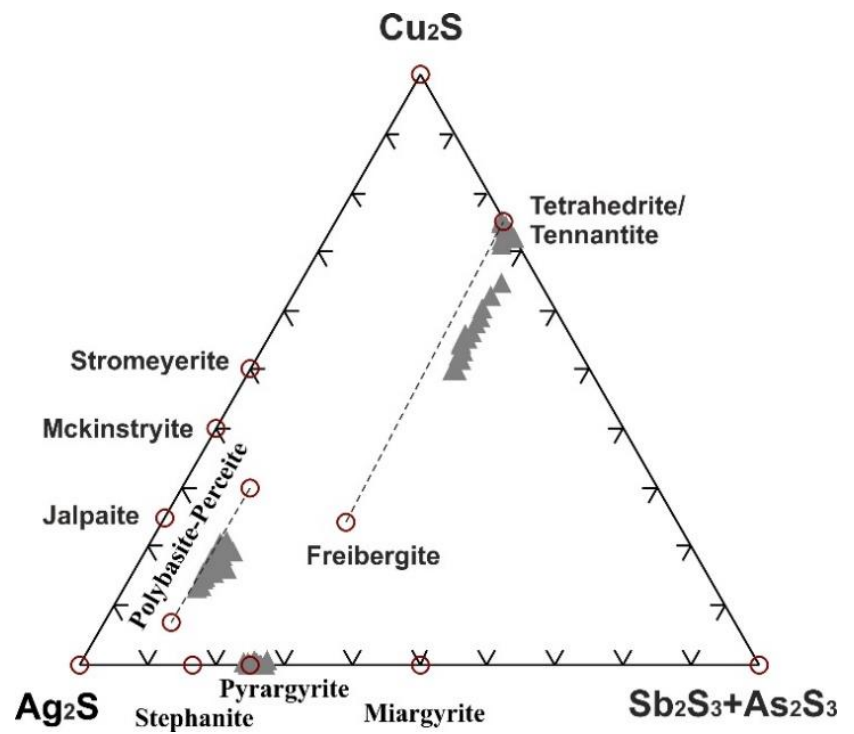

Figure 3 - Chemical composition of Ag-bearing sulfosalts in terms of the Ag-Cu-(Sb+As) ternary diagram (after Alfieris et al., 2013). Theoretical compositions are shown as open red circles. Filled triangles represent composition of the tetrahedrite-group minerals from Trades-Galana area. Compositional ranges of tetrahedrite-freibergite and polybasite solid solution are shown by dashed lines for reference. 
Table 2 - Representative microanalysis of galena (1-2), sphalerite (3), enargite (4), polybasite-pearceite (5-8), famatinite (9), tennantite-tetrahed rite series (10-14) and pyrargyrite (15-17).

\begin{tabular}{|c|c|c|c|c|c|c|c|c|c|c|c|c|c|c|c|c|c|}
\hline & 1 & 2 & 3 & 4 & 5 & 6 & 7 & 8 & 9 & 10 & 11 & 12 & 13 & 14 & 15 & 16 & 17 \\
\hline $\mathbf{C u}$ & & & - & 46.34 & 9.23 & 9.85 & 9.67 & 10.64 & 41.57 & 41.27 & 20.57 & 32.41 & 23.1 & 21.14 & & & 0.17 \\
\hline $\mathrm{Ag}$ & & - & & 0.38 & 65.56 & 66.18 & 61.84 & 55.78 & 1 & 3.3 & 13.77 & 9.76 & 15.07 & 14.16 & 57.38 & 59.67 & 60.07 \\
\hline $\mathrm{Fe}$ & - & - & 0.13 & 0.2 & & & & & 0.04 & 0.03 & & 0.3 & 0.18 & 2.47 & & & \\
\hline $\mathbf{Z n}$ & & & 66.55 & & & & & & & 0.19 & & 6.75 & 0.72 & 1.11 & & & \\
\hline $\mathrm{Sb}$ & - & 0.09 & - & 4.33 & 3.5 & 2.84 & 10.98 & 14.42 & 27.69 & 25.61 & 23.42 & 21.25 & 25.84 & 23.39 & 23.35 & 22.23 & 21.05 \\
\hline As & & & - & 16.6 & 4.76 & 3.66 & 0.47 & 0.02 & 1.01 & 0.04 & 0.57 & 5.39 & 0.16 & 0.54 & 0.01 & & \\
\hline Hg & - & - & - & - & - & - & - & - & - & - & 7.42 & - & & - & - & - & - \\
\hline Cd & - & - & 0.18 & - & - & - & - & - & - & - & 4.07 & - & 7.37 & 4.74 & . & . & . \\
\hline $\mathbf{P b}$ & 86.49 & 86.08 & - & - & - & - & - & - & - & - & 9.34 & - & 7.31 & 8.35 & - & - & . \\
\hline Mn & - & - & 0.02 & - & - & - & - & - & - & - & - & - & & 1.00 & - & - & - \\
\hline $\mathbf{S}$ & 13.32 & 13.34 & 32.4 & 31.36 & 15.52 & 16.17 & 16.55 & 17.01 & 28.45 & 28.68 & 19.76 & 24.04 & 21.78 & 22.97 & 18.68 & 18.3 & 18.11 \\
\hline Total & 99.82 & 99.51 & 99.27 & 99.22 & 98.59 & 98.72 & 99.52 & 99.87 & 99.77 & 99.13 & 98.95 & 99.91 & 101.53 & 99.86 & 99.39 & $\begin{array}{l}100.2 \\
\end{array}$ & 99.4 \\
\hline Ato & 2 & 2 & 2 & 8 & 29 & 29 & 29 & 29 & 8 & 8 & 29 & 29 & 29 & 29 & 7 & 7 & 7 \\
\hline $\mathrm{Cu}$ & 0.000 & 0.000 & 0.000 & 2.958 & 3.170 & 2.764 & 3.300 & 3.639 & 2.920 & 2.905 & 6.771 & 8.674 & 6.974 & 6.261 & 0.000 & 0.000 & 0.015 \\
\hline $\mathrm{Ag}$ & 0.000 & 0.000 & 0.000 & 0.014 & 13.259 & 13.227 & 12.424 & 11.243 & 0.042 & 0.137 & 2.671 & 1.537 & 2.680 & 2.471 & 2.894 & 2.964 & 3.005 \\
\hline $\mathrm{Fe}$ & 0.000 & 0.000 & 0.002 & 0.015 & 0.000 & 0.000 & 0.000 & 0.000 & 0.003 & 0.002 & 0.000 & 0.093 & 0.061 & 0.829 & 0.000 & 0.000 & 0.000 \\
\hline $\mathbf{Z n}$ & 0.000 & 0.000 & 1.002 & 0.000 & 0.000 & 0.000 & 0.000 & 0.000 & 0.000 & 0.014 & 0.000 & 1.757 & 0.212 & 0.319 & 0.000 & 0.000 & 0.000 \\
\hline $\mathrm{Sb}$ & 0.000 & 0.086 & 0.000 & 0.145 & 0.626 & 0.505 & $\begin{array}{l}1.955 \\
\end{array}$ & 2.575 & $\begin{array}{l}1.015 \\
\end{array}$ & 0.941 & 4.022 & 2.967 & 4.069 & 3.613 & 1.028 & 0.979 & 0.933 \\
\hline As & 0.000 & 0.000 & 0.000 & 0.899 & 1.386 & 1.056 & 0.136 & 0.060 & 0.061 & 0.002 & 0.157 & 1.224 & 0.041 & 0.133 & 0.001 & 0.000 & 0.000 \\
\hline $\mathrm{Hg}$ & 0.000 & 0.000 & 0.000 & 0.000 & 0.000 & 0.000 & 0.000 & 0.000 & 0.000 & 0.000 & 0.800 & 0.000 & 0.000 & 0.000 & 0.000 & 0.000 & 0.000 \\
\hline Cd & 0.000 & 0.000 & 0.002 & 0.000 & 0.000 & 0.000 & 0.000 & 0.000 & 0.000 & 0.000 & 0.000 & 0.000 & 0.000 & 0.792 & 0.000 & 0.000 & 0.000 \\
\hline $\mathbf{P b}$ & 1.002 & 0.998 & 0.000 & 0.000 & 0.000 & 0.000 & 0.000 & 0.000 & 0.000 & 0.000 & 0.942 & 0.000 & 0.658 & 0.760 & 0.000 & 0.000 & 0.000 \\
\hline Mn & 0.000 & 0.000 & 0.004 & 0.000 & 0.000 & 0.000 & 0.000 & 0.000 & 0.000 & 0.000 & 0.000 & 0.000 & 0.000 & 0.342 & 0.000 & 0.000 & 0.000 \\
\hline $\mathbf{S}$ & 0.997 & 1.000 & 0.994 & 3.486 & 10.559 & 10.872 & 11.188 & 11.533 & 3.960 & 3.999 & 12.896 & 12.748 & 13.030 & 13.476 & 3.123 & 3.058 & 3.047 \\
\hline
\end{tabular}

Table 3 - Representative bulk geochemical analyses from Trades-Galana area.

\begin{tabular}{|c|c|c|c|c|c|c|c|c|c|c|c|c|c|c|c|c|c|c|c|c|}
\hline & & TR-1 & TR-2 & TR-3 & TR-4 & TR-5 & TR-6 & TR-7 & TR-8 & TR-9 & TR-10 & TR-11 & TR-12 & TR-13 & GA-1 & GA-2 & GA-3 & GA-4 & GA-5 & GA-6 \\
\hline $\mathbf{Z n}$ & $\%$ & 0.01 & 0.003 & 0.88 & 2.99 & 15.0 & 0.39 & 9.14 & 0.15 & 3.80 & 3.36 & 0.43 & 2.56 & 3.92 & 0.08 & 0.02 & 0.06 & 1.73 & 3.01 & 4.10 \\
\hline $\mathbf{P b}$ & $\%$ & 0.05 & 0.002 & 0.50 & 0.45 & 0.71 & 0.09 & 0.86 & 0.16 & 0.58 & 3.27 & 0.31 & 1.44 & 0.81 & 1.05 & 0.27 & 2.13 & 1.46 & 0.75 & 1.99 \\
\hline $\mathrm{Cu}$ & $\%$ & 0.002 & 0.001 & 3.28 & 0.14 & 0.07 & 0.04 & 0.13 & 0.005 & 0.11 & 0.03 & 0.02 & 0.11 & 0.08 & 0.08 & 0.02 & 0.01 & 0.08 & 0.04 & 0.03 \\
\hline As & $\mathrm{mg} / \mathrm{kg}$ & 1210 & 33 & 7090 & 705 & 65 & 106 & 316 & 342 & 392 & 78 & 2040 & 281 & 278 & 305 & 43 & 19 & 32 & 15 & 21 \\
\hline Sb & $\mathrm{mg} / \mathrm{kg}$ & 317 & 2 & 22300 & 563 & 379 & 151 & 562 & 348 & 339 & 136 & 515 & 691 & 519 & 33 & 34 & 49 & 78 & 27 & 32 \\
\hline W & $\mathrm{mg} / \mathrm{kg}$ & 113 & 79 & 145 & 848 & 300 & 171 & 508 & 474 & 296 & 419 & 459 & 195 & 239 & 268 & 71 & 440 & 450 & 348 & 342 \\
\hline Cd & $\mathrm{mg} / \mathrm{kg}$ & 16 & 0.37 & 107 & 215 & 2370 & 15 & 665 & 4 & 219 & 203 & 16 & 109 & 297 & 2 & 2 & 4 & 106 & 236 & 225 \\
\hline Mo & $\mathrm{mg} / \mathrm{kg}$ & 265 & bdl & 42 & 5 & 41 & 17 & 21 & 99 & 28 & 7 & 92 & 22 & 44 & 9 & 4 & 8 & 7 & 7 & 10 \\
\hline Tl & $\mathrm{mg} / \mathrm{kg}$ & 55500 & 1730 & 724 & 1420 & 1040 & 1100 & 4690 & 12400 & 27900 & 705 & 89000 & 3290 & 4090 & 1270 & 2420 & 922 & 952 & 840 & 1670 \\
\hline $\mathbf{B i}$ & $\mathrm{mg} / \mathrm{kg}$ & 0.178 & 0.022 & 0.001 & 0.795 & 0.019 & 0.011 & 0.024 & 0.005 & 0.011 & 0.017 & 0.003 & 0.010 & 0.005 & 0.090 & 0.186 & 0.058 & 0.056 & 0.040 & 0.084 \\
\hline
\end{tabular}


Based on the geochemical data presented on Table 3, the samples from Triades are enriched in base metals (up to $15 \mathrm{wt}$. \% $\mathrm{Zn}$, up to $3.27 \mathrm{wt}$ \% $\mathrm{Pb}$, up to $3.28 \mathrm{wt}$. \% $\mathrm{Cu}$ ) compared to those from Galana.

The presence of Cd-bearing low-Fe sphalerite (Table 1) most probably could explain the elevated $\mathrm{Cd}$ concentrations in the bulk rock geochemical analyses (Triades: up to $2370 \mathrm{mg} / \mathrm{kg} \mathrm{Cd}$; Galana: $225 \mathrm{mg} / \mathrm{kg} \mathrm{Cd}$, Table 3). Similarly, the presence of abundant As- and Sb-bearing sulfosalts (e.g. enargite, famatinite, Ag-rich phases, etc.) at Triades compared to Galana are responsible for the elevated concentrations in the bulk rock geochemical analyses (Triades: up to $0.7 \mathrm{wt}$ \% As; up to 2.2 wt. \% Sb, Galana: up to $305 \mathrm{mg} / \mathrm{kg}$ As and up to $78 \mathrm{mg} / \mathrm{kg} \mathrm{Sb}$, Table 3). Tl with up to $89 \mathrm{mg} / \mathrm{kg}$ is highly enriched in Triades compared to Galana. Thallium-bearing sulfides and/or sulfosalts were not detected during our study, and most probably thallium is structurally bound in pyrite as suggested for Palaeochori, southern Milos by Katsouri et al. (2004) and Kati et al. (2015).

\section{Discussion - conclusions}

Precious metal-rich mineralization in western Milos Island was formed during the Upper Pliocene to Lower Pleistocene during the emplacement of three successive magma pulses (submarine to subaerial rhyodacite, andesite-dacite) in an emergent volcanic edifice (Alfieris et al., 2013; Kilias et al., 2001; Marchik et al., 2010; Naden et al., 2005). Mineralogical data indicate common features among the Profitis Ilias-Chondro Vouno, Kondaros-Katsimoutis-Vani and Triades-Galana mineralizations, all of them characterized by intermediate-sulfidation epithermal ore assemblages (e.g. Einaudi et al., 2003) including galena, iron-poor sphalerite, minor chalcopyrite and bariteadularia-sericite ( \pm calcite). At Triades-Galana fluctuations between intermediate- and highsulfidation states are indicated by the presence of enargite and famatinite in the mineralization (Alfieris et al., 2013). This study verifies earlier work by Alfieris (2006) and Alfieris et al. (2013) and suggests a common paragenetic sequence for both Triades and Galana with early deposition of pyrite followed by galena with tetrahedrite, polybasite, famatinite inclusions plus minor chalcopyrite, then by sphalerite and finally by a high-sulfidation ore assemblage composed of enargite, tennantite, hypogene covellite and late pyrite. Late pyrite occurs as colloform banded pyrite and framboids and is indicative of mineral deposition in a submarine environment (Vavelidis and Melfos 1998; Alfieris et al., 2013). Enargite was deposited during late introduction of As-bearing solutions in the mineralization, as is the case in other submarine settings (e.g. Brothers Volcano/Offshore New Zealand, Wetar island/Indonesia, etc.), where enargite is reported either as an early or late mineral (Sillitoe et al., 1996; de Ronde et al., 2011).

Naden et al. (2005) and Alfieris et al. (2013) suggest that metallic mineralization in western Milos Island formed under shallow water and partially emergent conditions that were the products of the mixing of seawater and magmatic water derived from subvolcanic sources. The seawater was sufficiently shallow near the top of the domes to allow boiling of ascending fluids (e.g. precipitation of adularia), and the formation of stockwork mineralization beneath the sea-floor. In common to other mineralization in northwestern Milos (e.g. Kondaros-Katsimouti and Vani; Alfieris et al., 2013; Glasby et al., 2005), the metallic mineralization in Triades-Galana area is highly enriched in Mo and W up to 265 and $848 \mathrm{mg} / \mathrm{kg}$, respectively. This enrichment extends over a surface area of about $15 \mathrm{~km}^{2}$ and is attributed to a buried granite at depth that fed volatiles and metals into the magmatic-hydrothermal system (Alfieris et al., 2013). Tungsten (e.g. scheelite) and Mo-bearing minerals (molybdenite) were not detected in the studied samples, however it is believed that they occur as early, high-temperature phases in the mineralizations. The subsequent evolution of the mineralization from Sb-, towards Asenrichment, may suggest a renewed magmatic pulse in the hydrothermal system associated with an input of As-rich magmatic gases. This evolution was consistent from early reduced and lower sulfidation, towards more oxidized and high-sulfidation conditions and took place under sub-seafloor to seafloor conditions respectively. The presence of lead chlorides included in galena, indicates involvement of seawater (in addition to magmatic water) for the mineralization. 


\section{References}

Alfieris, D., 2006. Geological, geochemical and mineralogical studies of shallow submarine epithermal mineralization in an emergent volcanic edifice, at western Milos island, Greece, $\mathrm{PhD}$ thesis, University of Hamburg, Germany, $211 \mathrm{pp}$.

Alfieris, D. and Voudouris, P., 2005. Ore mineralogy of transitional submarine to subaerial magmatic-hydrothermal deposits in W. Milos, Greece, In: Cook, N.G. and Bonev, I., eds., Au-Ag-Te-Se deposits, Geochemistry, Mineralogy and Petrology, 43, Sofia, 1-6.

Alfieris, D., Voudouris, P. and Spry, P.G., 2013. Shallow submarine epithermal Pb-Zn-Cu-Au-AgTe mineralization on western Milos Island, Aegean Volcanic Arc, Greece: Mineralogical, Geological and Geochemical constraints, Ore Geology Reviews, 53, 159-180.

Altherr, R. and Siebel, W., 2002. I-type plutonism in a continental back-arc setting:Miocene granitoids and monzonites from the central Aegean Sea, Greece, Contrib.Mineral.Petrol., 143, 397-415.

de Ronde, C.E., Massoth, G.J., Butterfield, D.A., Christenson, B.W., Ishibashi, J., Ditchburn, R.G., Hannington, M.D., Brathwaite, R.L., Lupton, J.E., Kamenetsky, V.S. and Graham, I.J., 2011. Submarine hydrothermal activity and gold-rich mineralization at Brothers Volcano, Kermadec Arc, New Zealand, Mineralium Deposita, 46(5-6), 541-584.

Einaudi, M.T., Hedenquist, J.W. and Inan, E.E., 2003. Sulfidation state of fluids in active and extinct hydrothermal systems: Transitions from porphyry to epithermal environments. In: Simmons, S.F. and Graham, I., eds., Volcanic, Geothermal, and oreforming fluids: Rulers and witnesses of processes within the Earth, Soc. Econ. Geol., Special Publication, 10, 285-313.

Fytikas, M., Innocenti, F., Kolios, N., Manneti, P., Mazzuoli, R., Poli, G., Rita, F. and Villari, L., 1986. Volcanology and petrology of volcanic products from the island of Milos and neighbouring islets, J. Volcanol. Geotherm. Res., 28, 297-317.

Glasby, G.P., Papavassiliou, C.T., Mitsis, J., Valsami-Jones, E., Liakopoulos, A. and Renner, R.M., 2005. The Vani manganese deposit, Milos island, Greece: a fossil stratabound $\mathrm{Mn}-\mathrm{Ba}-\mathrm{Pb}-$ Zn-As-Sb-W-rich hydrothermal deposit. In: Fytikas, M. and Vougioukalakis, G.E., eds., The South Aegean Active Volcanic Arc: Present Knowledge and Future Perspectives, Developments in Volcanology, 7, Elsevier, 255-291.

Hauck, M., 1988. Kuroko-type ore deposits on the Aegean Islands, Greece. In: Friedrich, G.M. and Herzig, P.M., eds., Base metal sulfide deposits, Springer Verlag, Berlin, 216-228.

Jolivet, L., and Brun, J.P., 2010. Cenozoic geodynamic evolution of the Aegean region, Int. J. Earth Sci., 99, 109-138.

Kati, M., Voudouris, P., Valsami-Jones, E., Magganas, A., Baltatzis, E., Kanellopoulos, C. and Mavrogonatos, C., 2015, April. Cinnabar, arsenian pyrite and thallium-enrichment in active shallow submarine hydrothermal vents at Paleochori Bay, Milos Island, Greece, EGU General Assembly Conference Abstracts, 17, 13046 pp.

Katsouri, S., Scott, S.D., Gorton, M.P., Magganas, A., Valsami-Jones, E., Baltatzis, E. and Kati, M., 2004. Formation of hydrothermal sulphides in active shallow water systems: the role of freshwater vs seawater, SEG Eugen Stumpfl Memorial Symposium, Predictive Mineral Discovery Under Cover. Seccion, 1, 220-223.

Kilias, S.P., Naden, J., Cheliotis, I., Shepherd, T.J., Constandinidou, H., Crossing, J. and Simos, I., 2001. Epithermal gold mineralisation in the active Aegean volcanic arc: the ProfitisIlias deposit, Milos Island, Greece, Miner. Deposita, 36, 32-44.

Kilias, S.P., Nomikou, P., Papanikolaou, D., Polymenakou, P.N., Godelitsas, A., Argyraki, A., Carey, S., Gamaletsos, P., Mertzimekis, T.J., Stathopoulou, E. and Goettlicher, J., 2013. New insights into hydrothermal vent processes in the unique shallow-submarine arc-volcano, Kolumbo (Santorini), Greece, Scientific Reports, 3, 2421, 1-13.

Liakopoulos, A., Glasby, G.P., Papavassiliou, C.T. and Boulegue, J., 2001. Nature and origin of the Vani manganese deposit, Milos, Greece: an overview, Ore Geol Rev, 18, 181-209.

Marschik, R., Bauer, T., Hensler, A.S., Skarpelis, N. and Holzl, S., 2010. Isotope Geochemistry of the $\mathrm{Pb}-\mathrm{Zn}-\mathrm{Ba}(-\mathrm{Ag}-\mathrm{Au})$ Mineralization at Triades-Galana, Milos Island, Greece, Res. Geology, 60, 335-347. 
Naden, J., Kilias, S.P. and Darbyshire, D.B.F., 2005. Active geothermal systems with entrained seawater as analogues for transitional continental magmato-hydrothermal and volcanichosted massive sulfide mineralization-the example of Milos Island, Greece, Geology, 33, 541-544.

Plimer, I., 2000. Milos Geologic History. KOAN Publishing House, Athens, 262 pp.

Scotney, P.M., Roberts, S., Herrngton, R.J., Boyce, A.J. and Burgess, R., 2005. The development of volcanic hosted massive aulfide and barite gold orebodies on Wetar Island, Idonesia, Mineralium Deposita, 40, 76-99.

Shimizu, M., Kato, A., Matsubara, S., Criddle, A.J. and Stanley, C.J., 1993. Watanabeite, $\mathrm{Cu}_{4}(\mathrm{As}, \mathrm{Sb})_{2} \mathrm{~S}_{5}$, a new mineral from the Teine mine, Sapporo, Hokkaido, Japan, Mineral. Mag., 57, 643-649.

Sillitoe, R.H., Hannington, M.D. and Thompson, J.F.H., 1996. High-sulfidation deposits in the volcanogenic massive sulfide environment, Econ. Geol., 91, 204-212.

Stewart, A.L. and McPhie, J., 2003. Setting of epithermal Au deposits in a modern volcanic island arc setting, Milos, Greece: Implications for mineral exploration, Mineral Exploration and Sustainable Development. Millpress, Rotterdam, 533-536.

Stewart, A.L. and McPhie, J., 2006. Facies architecture and Late Pliocene-Pleistocene evolution of a felsic volcanic island, Milos, Greece, Bull. Volcanol., 68, 703-726.

Vavelidis, M. and Melfos, V., 1997. Two plumbian tetrahedrite-tennantite occurrences from Maronia area (Thrace) and Milos island (Aegean Sea, Greece), Eur. J. Mineral., 9, 653-657.

Vavelidis, M. and Melfos, V., 1998. Fluid inclusion evidence for the origin of the barite silver-goldbearing $\mathrm{Pb}-\mathrm{Zn}$ mineralization of the Triades area, Milos Island, Greece, Bull. Geol. Soc. Greece, 32, 137-144. 